\title{
Scale-Up Marketing and Export of MSME Products Based on Digital Business at MEK-PDM Gresik
}

\author{
Author \\ Efta Dhartikasari Priyana (ORCID ID. 0000-0002-3759-7790) \\ Abdurrahman Faris Indriya Himawan (ORCID ID. 0000-0003-4842-2600) \\ Correspondence \\ Universitas Muhammadiyah Gresik, East Java, Indonesia \\ Eftadhartikasari@umg.ac.id, Faris@umg.ac.id
}

\begin{abstract}
:
The low quality of Human Resources which ultimately leads to the ineffectiveness of management, organization and technology has made the development of MSMEs in Indonesia unable to touch rapidly. Plus the large transaction costs from the impact of an unfavorable business climate are also a problem for the case of MSMEs fostered by MEK-PDM Gresik, making it difficult to compete in the international market. In fact, the products produced by MSMEs are no less competitive with those produced by foreign products. In fact, to be able to penetrate the global market, MSMEs must at least be able to adapt to the concept of global marketing which is not yet owned by MSME stakeholders. Therefore, in this service, MSME actors will be taught how to market their products globally. Fronted by Dr. Indro Kirono as a performer who previously had a long history in the export world, the service event went more than imagined. Many MSME products were independently assisted by the presenters to be introduced a little in the global market. Gresik UMKM products will also be assisted by the introduction of Gresik Muhammadiyah University. So that Muhammadiyah University of Gresik can become a place for Gresik SMEs to be fostered.
\end{abstract}

Keywords: Digital Marketing, Export, MEK_PDM, Products.

\section{Introduction}

The development of Micro, Small and Medium Enterprises (MSMEs) that have existed in Indonesia, especially Gresik, has not been matched by improving the quality of MSMEs themselves. This is not far from the internal problems that exist within MSMEs themselves. The quality of Human Resources, organization, mastery of technology and marketing are some of the classic problems that are often faced by MSMEs themselves. Plus the existence of external problems such as capital, information, technology and markets is another job that needs attention.

The inability of MSMEs in dealing with internal and external problems that occur among themselves, makes many MSMEs in Indonesia not yet have strong enough competitiveness to be able to penetrate the international arena. Here, the encouragement of adequate quality goods does not seem to be able to make them marketable. The many requirements to penetrate the global market, with special requirements that are somewhat different on each continent, make mapping for exports also have to be done.

The development of e-commerce which is quite mushrooming in the global community, especially in Indonesia, seems to provide new space for MSME players to market their business. The use of digital technology that facilitates marketing activities
Received: 23 August 2021. Accepted: 23 December 2021.

has indeed been proven to be able to help every access to introductions and even product sales from abroad.

But wait, it turns out that even though it sounds quite classic, import-export marketing to foreign countries, whether in digital form, is not as easy as turning the palm of the hand. There is an important role that needs to be considered by MSME actors, namely the culture in the destination country. The culture referred to here can be a special requirement that must be met by the exporting country. An example is the export of coffee products, which in fact in some countries only accept in the form of beans, while others allow shipments in the form of coffee grounds. Not to mention that there are several export conditions given by the distributor for delivery.

Therefore, the service group organized by the Muhammadiyah Research grant made a new breakthrough, namely providing product export training. By managing the MSMEs assisted by MEK_PDM Gresik, it is hoped that many of the MSMEs fostered can penetrate their products to foreign countries.

Accompanied by Dr. Indro Kirono, an export expert who has been devoted to the world of export for a long time, it is hoped that the participants can gain a lot of knowledge and be able 
to process their MSME products towards going international. And the result is extraordinary than expected.

Some products from SMEs that are ready for export, assisted by Dr. Indro Kirono to be introduced abroad and others are reviewed for their products to be export worthy. They are also asked to study export documents and the special requirements that exist in each country,

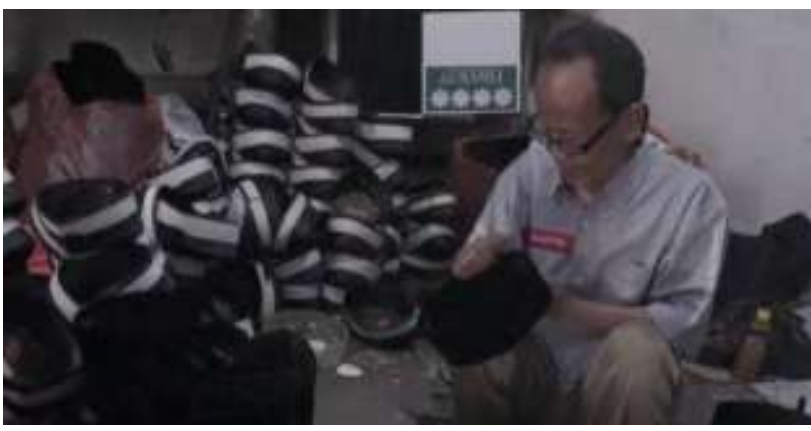

Figure 1. Songkok Ramli Craftsmen Assisted by MEK-PDM Gresik

Table 1. Data on the Number of MSMEs assisted by MEK-PDM Gresik

\begin{tabular}{|c|c|c|c|c|}
\hline \multirow{2}{*}{ No } & Criteria & \multicolumn{3}{|c|}{ Jumlah } \\
\cline { 3 - 5 } & 2017 & 2018 & 2019 \\
\hline 1 & $\begin{array}{c}\text { Food-Beverage } \\
\text { Business }\end{array}$ & 5 & 9 & 17 \\
\hline 2 & $\begin{array}{c}\text { Fashion and } \\
\text { Convection Business }\end{array}$ & 13 & 17 & 21 \\
\hline 3 & Artwork Business & 2 & 2 & 1 \\
\hline 4 & $\begin{array}{c}\text { Miscellaneous } \\
\text { Business }\end{array}$ & 10 & 18 & 23 \\
\hline
\end{tabular}

\section{Methods}

Based on the background of the problems discussed in the previous chapter, the application of training and assistance in digital marketing integration in improving product export quality standards by understanding the documents included are as follows.

Table 2. Creating Digital Commerce

\begin{tabular}{|c|c|c|}
\hline $\begin{array}{c}\text { Themes and } \\
\text { Materials }\end{array}$ & Target & $\begin{array}{c}\text { Forms of } \\
\text { Activity }\end{array}$ \\
\hline $\begin{array}{l}\text { 1. Create } \\
\text { Email } \\
\text { 2. Create a } \\
\text { Blog / Online } \\
\text { Store. } \\
\text { 3. Designing } \\
\text { an Online } \\
\text { Store }\end{array}$ & $\begin{array}{l}\text { 1. Participants can } \\
\text { create and be skilled } \\
\text { at updating and } \\
\text { upgrading each } \\
\text { content. } \\
\text { 2. Skilled participants } \\
\text { in designing online } \\
\text { stores so that they are } \\
\text { neat and beautiful. }\end{array}$ & $\begin{array}{l}\text { Practice } \\
\text { exposure } \\
\text { and } \\
\text { discussion }\end{array}$ \\
\hline
\end{tabular}

\section{Filling the \\ Online Store}

Content

Table 3. Creating Promotional Media

\begin{tabular}{|l|l|l|}
\hline $\begin{array}{c}\text { Themes and } \\
\text { Materials }\end{array}$ & \multicolumn{1}{|c|}{ Target } & \multicolumn{1}{|c|}{$\begin{array}{c}\text { Forms of } \\
\text { Activity }\end{array}$} \\
\hline 1. Instagram & 1. Skilled & Exposure, \\
Paid Promote & Participants in & Practice, \\
2. Facebook & Creating Facebook & Discussion. \\
Marketing & and Optimizing it as & \\
3. Instagram & a Media Offer by & \\
Marketing & using the facilities & \\
4. Youtube & provided by & \\
and Making & facebook a.l.: & \\
Movies/Video & Fanpage, Group, & \\
s Simple & Inbox, Status, Note, & \\
Production & and Events. & \\
Process. & 2. Participants are & \\
& also familiar with & \\
& and skilled in using & \\
& other media as & \\
& media for product & \\
& offerings such as & \\
& Instagram, and & \\
& Youtube. & \\
& Participants can & \\
& make simple videos. & \\
\end{tabular}

Table 4. Online Advertising

\begin{tabular}{|c|c|c|}
\hline $\begin{array}{c}\text { Themes and } \\
\text { Materials }\end{array}$ & Target & $\begin{array}{c}\text { Forms of } \\
\text { Activity }\end{array}$ \\
\hline $\begin{array}{l}\text { 1. Preview the } \\
\text { effectiveness } \\
\text { and important } \\
\text { role of } \\
\text { advertising in } \\
\text { supporting } \\
\text { online } \\
\text { business. } \\
\text { 2. Create a } \\
\text { free animated } \\
\text { banner. Either } \\
\text { flash program } \\
\text { or animated } \\
\text { gif. } \\
\text { 3. Create and } \\
\text { install targeted } \\
\text { and segmented } \\
\text { free ads. } \\
\text { 4. Perform ad } \\
\text { optimization. }\end{array}$ & $\begin{array}{l}\text { 1. Understand the } \\
\text { role of } \\
\text { advertising as a } \\
\text { medium, an } \\
\text { effective offering. } \\
\text { 2. Able to make a } \\
\text { good ad design. } \\
\text { 3. Able to } \\
\text { advertise and } \\
\text { optimize it. } \\
\text { 4. Able to make } \\
\text { the right target } \\
\text { for products and } \\
\text { prospective } \\
\text { buyers with } \\
\text { money }\end{array}$ & $\begin{array}{l}\text { Exposure, } \\
\text { Practice, } \\
\text { Discussion. }\end{array}$ \\
\hline
\end{tabular}

Table 5. Import Export Documents

\begin{tabular}{|l|l|l|}
\hline \multicolumn{1}{|c|}{$\begin{array}{c}\text { Themes and } \\
\text { Materials }\end{array}$} & \multicolumn{1}{|c|}{ Target } & \multicolumn{1}{|c|}{$\begin{array}{c}\text { Forms of } \\
\text { Activity }\end{array}$} \\
\hline 1. Financial & 1. Able to make & Exposure, \\
Documents & export documents & Practice, \\
2. Shipping & correctly & Discussion. \\
Documents & & \\
\hline
\end{tabular}




\begin{tabular}{|l|l|l|}
\hline 3. & 2. Able to read & \\
Commercial & export documents & \\
Invoice & correctly & \\
4. & \\
Packing/Weig & \\
ht List & \\
5. Marine & \\
Insurance & \\
6. Certificate & \\
of Origin & \\
(SKA) & \\
7. Transport & \\
Documents & \\
(B/L, AWB) & \\
8. B/L & \\
function, & \\
AWB & \\
9. Matters & \\
that need to & \\
be considered & \\
in the B/L & \\
10. How to & \\
Transfer/Endo & \\
rsement B/L & & \\
\hline
\end{tabular}

\section{Results and Discussion}

Exposure of several procedures for organizing workshops that have been carried out. Then the service work scheme is as follows:

\section{Digital Commerce Creation}

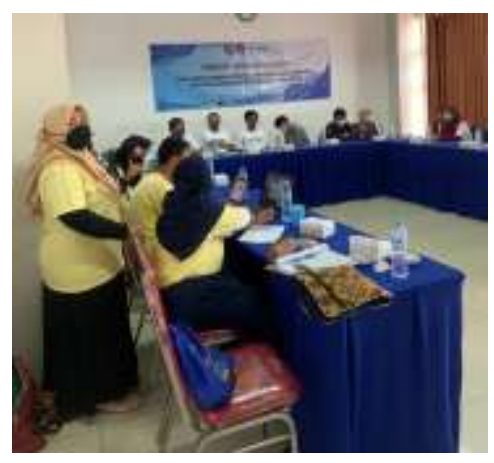

Figure 2. Digital Commerce Training

At this stage, participants will be provided with how to create emails, online stores from e-commerce, store designs online and fill in the content of the products they have. From the training carried out at this stage, some people already have an online store, but with an ordinary design. Some of the rest still market their products through offline stores.
2. Making Promotional Media

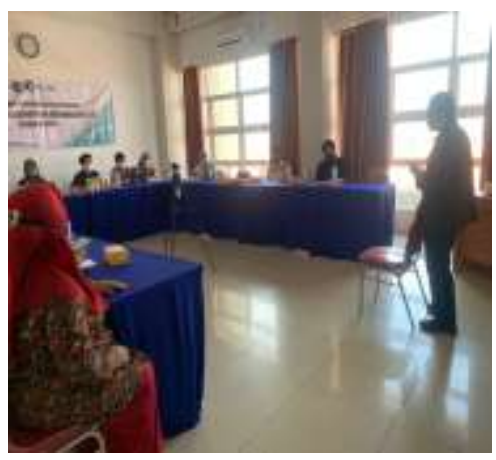

Figure 3. Making Promotional Media

Marketing in the digital era is not far from the applications or tools used. In this case the training is about how to use Instagram, Facebook, YouTube for media marketing. We know that the media is not a rare thing to know. But not many people know how to use it as a marketing tool.

3. Placing Online Ads

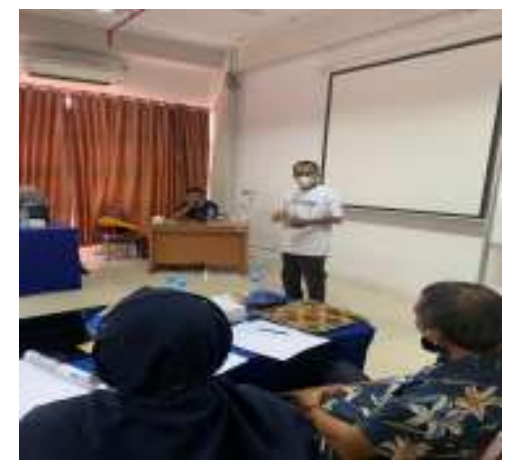

Figure 4. Participants Explain How to Place Ads

From the previous training reference, the next is advertising training. How to find free advertising opportunities for our products. And what is the importance of advertising for our product marketing.

4. Import Export Documents

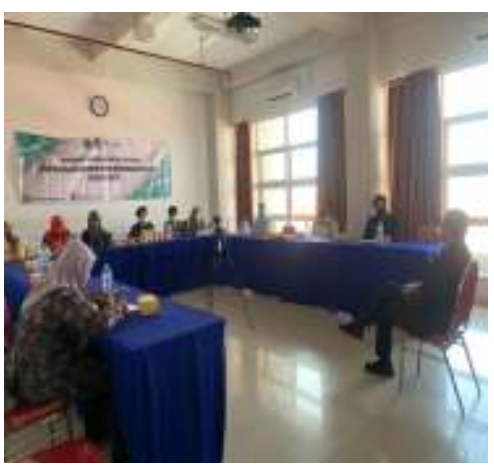

Figure 5. Explanation of Import Export 
The next stage is the main event, which is an explanation of import-export products. Where here are described several documents that must be prepared, what are the most important considerations in choosing an export destination country, and what risks are involved in distribution abroad.

\section{Exposure to Import Export Procedures}

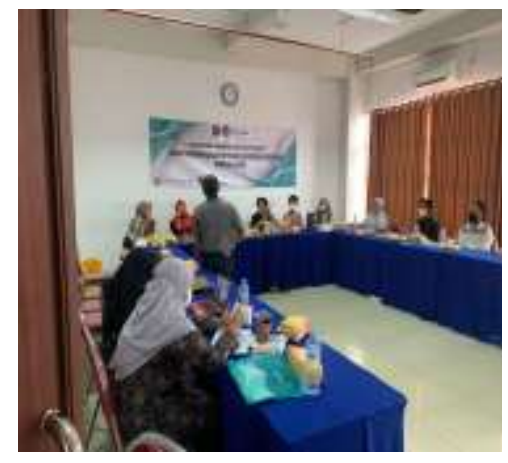

Figure 6. Speakers See Some of the Participants' Products. The export-import procedure here is more towards quality than the product itself.

\section{Conclusion}

Is in accordance with the standards that have been given by the destination country. How to risk the goods themselves through the procedure of several documents. The last event on the second day was closing. The closing ends with a group photo. Presenting mementos to the presenters. And handed out several door prizes on superior products.

\section{References}

Directorate of Research and Community Service. 2020. Research Guide and Community Service Edition XIII. Kemenristek/BRIN : Jakarta.

Himawan, Abdurrahman. 2019. Positioning Travel Sites Online Traveloka According to Student Perception in Gresik using Method Multidimensional Scaling. AFBE 2019.

Himawan, Abdurrahman. 2020. Growing Women's Interest In Entrepreneurship In Sonoadi Village Through Sonoadi Entrepreneurship Seminars. DedikasiMu (Journal Of Community Service.

Himawan, Abdurrahman. 2020. Determining Factors of Millennial Consumer Loyalty in Purchasing Decisions at Traveloka Online Travel Agency (OTA) (Study of Muhamadiyah Gresik University Students). UMMagelang Conference Series.
MEK TEAM. 2020. MEK PDM Gresik in Figures. Regional Leaders' Economic \& Entrepreneurship Council. Gresik : Gresik.

Priyana. E.D., 2020. Development Of Granule Form Making Fertilizers In Muhammadiyah 3 Morowudi Gresik Vocational School. Innovation Research Journal.

Priyana. E.D., 2020. Feasibility Analysis Of Opening New Integrated Market Needs In The Gresik Environment With Statistical Approach. Journal INTECH

Priyana. E.D., 2021. Facilities Development and Socialization of Bule-Brazilians in Buckets (Guide for The Event of Community Economic Independence). Innovation Research Journal. 